\title{
16. HYDROGEN ISOTOPE COMPOSITION OF PORE WATERS AND INTERLAYER WATER IN SEDIMENTS FROM THE CENTRAL WESTERN PACIFIC, LEG 129'
}

\author{
Christian France-Lanord ${ }^{2}$ and Simon M.F. Sheppard ${ }^{2,3}$
}

\begin{abstract}
Hydrogen isotope compositions have been measured on pore waters from sediments of Leg 129 sites in the Pigafetta and East Mariana basins (central western Pacific). Total water (pore + sorbed waters) contents and their $\delta \mathrm{D}$ have been analyzed for three samples that contain smectite but no zeolite so that sorbed water can be attributed to interlayer water. The $\mathrm{H}$ budget for pore and total waters implies that interlayer water is $20 \%$ to $30 \%$ depleted in D compared to pore water. Because the interlayer/total water molar ratio $(0.25$ to 0.5$)$ in smectitic sediments is very high, interlayer water represents an important reservoir of D-depleted water in sediments.

$\delta$ D depth profiles for pore water at Sites 800 and 801 show breaks related to chert and radiolarite layers and are relatively vertical below. Above these chert units, pore waters are similar to modern seawater but below, they are between $-10 \%$ and $-5.5 \%$. These values could represent little modified pre-Miocene seawater values, which were D-depleted because of the absence of polar caps, and were preserved from diffusive exchange with modern seawater by the relatively impermeable overlying chert layers. At Site $802, \delta \mathrm{D}$ values of the pore waters show a decrease in the Miocene tuffs from $0 \%$ values at the top to $-8 \%$ at $250 \mathrm{mbsf}$. Below, $\delta \mathrm{D}$ values are relatively uniform at about $-8 \%$. Miocene tuffs are undergoing low water/rock alteration. A positive covariation of $\delta \mathrm{D}$ and $\mathrm{Cl}$ content of pore water in the tuffs suggests that the increase of $\delta \mathrm{D}$ values could result from secondary smectite formation. Low diffusive exchange coupled with D enrichment due to alteration of preglacial waters could explain the observed profile.
\end{abstract}

\section{INTRODUCTION}

Hydrogen is a major element in deep-sea sediments. It is present as (1) pore water, (2) absorbed water as interlayer (or interlamellar) water in swelling clays (e.g., smectites and saponite), zeolitic or channel water in zeolites, etc., (3) adsorbed water on mineral surfaces, and (4) structurally bound hydroxyl. Absorbed and adsorbed water, which are referred to here as sorbed water (e.g., Newman, 1987), are not readily physically separated when they are present together. Thus, hydrogen is considered here to be distributed among three sites: pore water, sorbed water, and hydroxyl hydrogen. The bulk hydrogen content of the sample is therefore represented by the sum of these three reservoirs. Although it is often presented as the bulk water content of the sample, part of the hydrogen is present as hydroxyl. Sorbed waters are exchangeable with free water in minutes to days (Moum and Rosenqvist, 1958; Savin and Epstein, 1970). The processes controlling the distribution of hydrogen among the three sites and their $\mathrm{H}$ isotope compositions remain debatable, largely because of the difficulties of sampling these different sites in the same sample. Characterizing the amount of hydrogen in the different sites and their isotopic compositions is necessary to conduct a mass balance for hydrogen and to elucidate the processes that control its distribution in pore waters.

Numerous analyses of pore water in Deep Sea Drilling Project-Ocean Drilling Program (DSDP-ODP) holes have shown that $\delta \mathrm{D}$ values usually decrease with depth by $5 \%$ to $15 \%$ (e.g., Lawrence, 1988). In a few examples, $\delta \mathrm{D}$ values start to increase by $5 \%$ to $10 \%$ in the first 50 to $100 \mathrm{~m}$ below seafloor (mbsf) and then decrease (e.g., DSDP Sites 149, 225, 229, and 231; Friedman and Hardcastle, 1988). The $\delta \mathrm{D}$ of contemporaneous seawater, diffusive exchange with seawater and the upper oceanic crust, diagenetic reactions, ultrafiltration

\footnotetext{
${ }^{1}$ Larson, R. L., Lancelot, Y., et al., 1992. Proc. ODP, Sci. Results, 129: College Station, TX (Ocean Drilling Program).

${ }^{2}$ Centre de recherches pétrographiques et géochimiques-CNRS, BP 20, 54501 Vandoeuvre Cedex, France.

${ }^{3}$ Current address: Laboratoire de géologie, école normale supérieure de Lyon, 46 allée d'Italie, 69364 Lyon Cedex 7. France.
}

through clay "membranes," mantle $\mathrm{H}_{2}$ and $\mathrm{CH}_{4}$ degassing, and organic matter reactions are all parameters and processes that may influence the $\delta \mathrm{D}$ value of pore water between its entrapment in the sediments and the time it is squeezed out as a water sample. Because hydrogen from interlayer water is twice as abundant as hydroxyl-hydrogen in smectite, the effect of diagenetic reactions on pore-water isotopic composition cannot be modeled correctly without precise knowledge of the amount and isotopic composition of sorbed water.

In this paper a new sampling technique is applied for the first time so that the distribution and isotopic composition of $\mathrm{H}$ in the three principal reservoirs could be measured or calculated from three sites drilled during Leg 129 (western Pacific, Fig. 1). For three samples the $\mathrm{H}$ isotope fractionation between sorbed water and pore water is estimated and then applied to indicate the effects of secondary smectite formation on the isotopic composition of pore water. At these Leg 129 sites, volcaniclastic sediments rich in smectites and zeolites are abundant; the effects of diagenetic reactions on the chemical and $\mathrm{Sr}$ isotope compositions of pore water are dominant, and even exceptional at Site 802 (France-Lanord et al., this volume; Alt and Burdett, this volume; Karpoff et al., this volume).

\section{ANALYTICAL TECHNIQUES}

Pore-water samples were extracted by squeezing 5- to $10-\mathrm{cm}$-long whole-round core sections at room temperature in a titanium and stainless steel piston modified after Manheim and Sayles (1974). Samples were stored in sealed glass bottles or polyethylene tubes.

Microcores of sediments were sampled on whole-round core sections before squeezing by using a 6 -mm-diameter stainless steel piston. Immediately after coring the microcore was ejected from the piston into a weighed quartz tube, reweighed, and sealed with a torch. Bulk sediment weight (solid plus waters) was about $0.8 \mathrm{~g}$. This corresponds to 0.3 to $0.6 \mathrm{~g}$ of "total" water, defined as the water in the pores and sorbed. It does not include the hydroxyl hydrogen which at the low temperatures of the sediments is taken to be nonexchangeable. Extraction of total water was done after breaking the ampoule under vacuum and heating to $140^{\circ} \mathrm{C}$ for $20 \mathrm{hr}$. In detail this extraction 


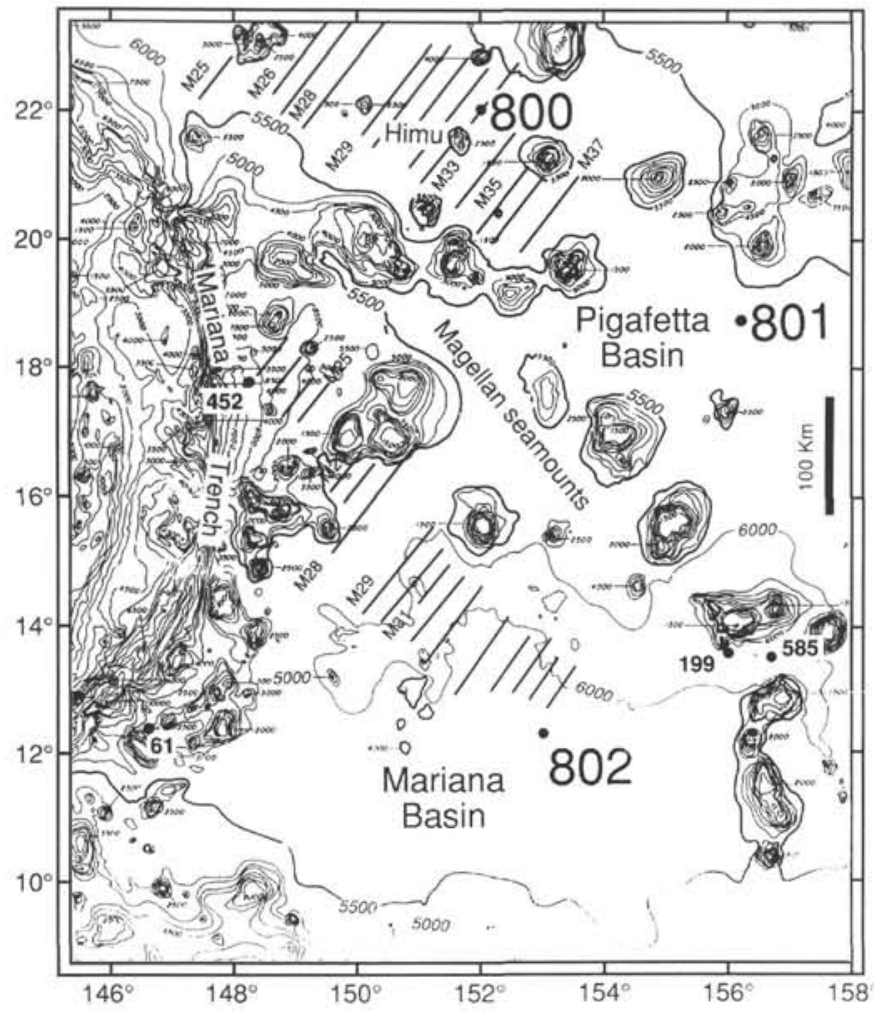

Figure 1. Location of Sites 800,801 , and 802 and other DSDP sites in the area of the Pigafetta and East Mariana basins (Lancelot, Larson, et al., 1990). Bathymetry in meters. Diagonal lines denote magnetic anomalies.

procedure may not remove all of the interlayer water because in smectites a small fraction of the interlayer water remains to much higher temperatures at which hydroxyl "water" begins to be liberated. For experimental reasons, therefore, the total water content of the sample neglects this residual interlayer water. The released water was trapped in a sample tube cooled by liquid nitrogen. The liberated water was precisely weighed to measure the total water content of the sediment. The residual sediment, which is termed dry sediment, was then heated to $1000^{\circ} \mathrm{C}$ in the same tube to release hydroxyl hydrogen and to determine its content, expressed as $\mathrm{H}_{2} \mathrm{O}^{+}$wt $\%$.

Water samples of 100 to $300 \mu \mathrm{mol}$ were converted to $\mathrm{H}_{2}$ over uranium metal at $800^{\circ} \mathrm{C}$ (Bigeleisen et al., 1952). $\mathrm{H}_{2}$ gas was analyzed on a VG $602 \mathrm{D}$ mass spectrometer. Overall reproducibility is $\pm 1 \%$.

\section{SITE DESCRIPTIONS AND RESULTS}

Sites 800,801 , and 802 were drilled in the Pigafetta and East Mariana basins (Fig. 1) to recover Jurassic sediments and oceanic crust (Lancelot, Larson, et al., 1990). Only Site 801 achieved this goal. These materials are the first direct record of this part of the Jurassic superocean.

Hydrogen isotopic profiles of pore waters are presented in Figure 2 and the data are listed in Table 1. For the same set of samples, mineralogy, pore-water chemistry, and $\mathrm{Sr}$ isotopic compositions are given and discussed in France-Lanord et al. (this volume) and sulfur isotope compositions in Alt and Burdett (this volume). Total water analyses have been done on three samples from Site 800 selected because they contained smectite and no zeolites; hence, sorbed water in these samples can only be attributed to smectite.

\section{Site 800-Pigafetta Basin}

Site 800 is located at a depth of $5686 \mathrm{~m}$ in northern Pigafetta Basin, 40 miles northeast of Himu Seamount (Fig. 1). The sediments (498 m) range in age from Cenozoic to Berriasian and have been divided into five lithologic units ("Site 800" chapter, Lancelot, Larson, et al., 1990) (Fig. 2):

Unit I (0-38 mbsf): Tertiary to upper Campanian zeolitic pelagic brown clay.

Unit II (38-78 mbsf): upper Campanian to Turonian brown chert and porcellanite.

Unit III (78-229 mbsf): Cenomanian to lower Albian gray chert and limestones.

Unit IV (229-450 mbsf): Aptian volcaniclastic turbidites possibly from Himu Seamount. The altered volcanic material is dominated by smectite minerals. Clinoptilolite and philipsite are present in the upper half of the unit.

Unit V (450-498 mbsf): Hauterivian to Berriasian claystone and radiolarite.

The sediment sequence overlies massive dolerite sills.

\section{Pore Water}

$\mathrm{D} / \mathrm{H}$ analyses of pore waters are listed in Table 1 and the $\delta \mathrm{D}$ depth profile is shown in Figure 2. Eight pore-water samples were squeezed; one in Unit I and seven in Units IV andV. Because of the nature of the lithology and scarce recovery no samples were taken in Units II and III. In Unit I, at $22 \mathrm{mbsf}, \delta \mathrm{D}$ value of pore water is indistinguishable from that of seawater. Below the chert and radiolarite Units II and III, pore waters are depleted in D relative to modern seawater. The $\delta \mathrm{D}$ profile shows a slight decrease with depth from values at about $-7 \%$ at the top of Unit IV to $-9 \%$ at the bottom of the hole. $\delta \mathrm{D}$ of smectite hydroxyl water from Samples 129-800A-37R-2, 0-10 cm, and 129-800A-49R-2, $140-150 \mathrm{~cm}$, are $-48.9 \%$ and $-53.6 \%$, respectively (Table 2), and $\mathrm{OH}$-pore-water fractionations are -43.0 and -46.1 . These values correspond to isotopic temperatures of $15^{\circ} \mathrm{C}$ and $3^{\circ} \mathrm{C} \pm 15^{\circ}$, respectively, if one applies the empirical smectite-water fractionation curve of Yeh (1980). If the errors are taken into account, these temperatures are consistent with estimated present temperatures of $13^{\circ} \mathrm{C}$ and $17^{\circ} \mathrm{C}$, respectively (Fisher, pers. comm., 1991). However, it is probable that much of the smectite was produced earlier at a lower temperature.

\section{Total Water}

Analyses of the total water (the water released at $140^{\circ} \mathrm{C}$, i.e., pore + sorbed water) from sealed microcores were made on three samples in which smectite is the only phase containing significant sorbed water. The clay mineralogy of these samples is described in Karpoff (this volume). In Sample 129-800A-37R-2, 0-10 cm, X-ray diffraction (XRD) determination indicates that the sample is dominated by far by a di-trioctahedral $\mathrm{Mg}$-rich smectite with traces of volcanic minerals. The amount of smectite cannot be determined precisely because the chemical composition of the different phases in not known. Based on the XRD, the chemical composition (France-Lanord et al., this volume) and the hydroxyl content (Table 2) the smectite represents about $90 \mathrm{wt} \%$ of the sample with a lower limit at $70 \mathrm{wt} \%$ based only on the hydroxyl content. Scanning electron microscope (SEM) observations on the $<2-\mu \mathrm{m}$ fraction show that, in addition to large flocky smectite particles, there are small laths $(<0.4 \mu \mathrm{m})$ that are probably celadonite. In Sample 129-800A-49R-2, 140-150 cm, two types of smectite (di-trioctahedral and dioctahedral) are the only minerals determined by XRD. Both are large, flocky particles on SEM observations. As for the previous sample the smectite content is about $90 \mathrm{wt} \%$ with a lower limit at $60 \mathrm{wt} \%$. Sample $129-800 \mathrm{~A}-54 \mathrm{R}-2,0-12$ $\mathrm{cm}$, is a clayey radiolarite containing quartz, di-octahedral authigenic smectite, and hematite. Smectite content is about $35 \mathrm{wt} \%$ with a lower limit at $25 \mathrm{wt} \%$ and quartz represents about $60 \mathrm{wt} \%$ of the sample.

Analytical results are reported in Table 2 for pore water and total water. Total waters are always depleted in D compared to pore water. The difference is $3.9 \%$ for Sample 129-800A-37R-2, 0-10 cm, 7.2\%o for Sample 129-800A-49R-2, 140-150 cm, and 6.7\% for Sample 129-800A$54 \mathrm{R}-2,0-12 \mathrm{~cm}$. 


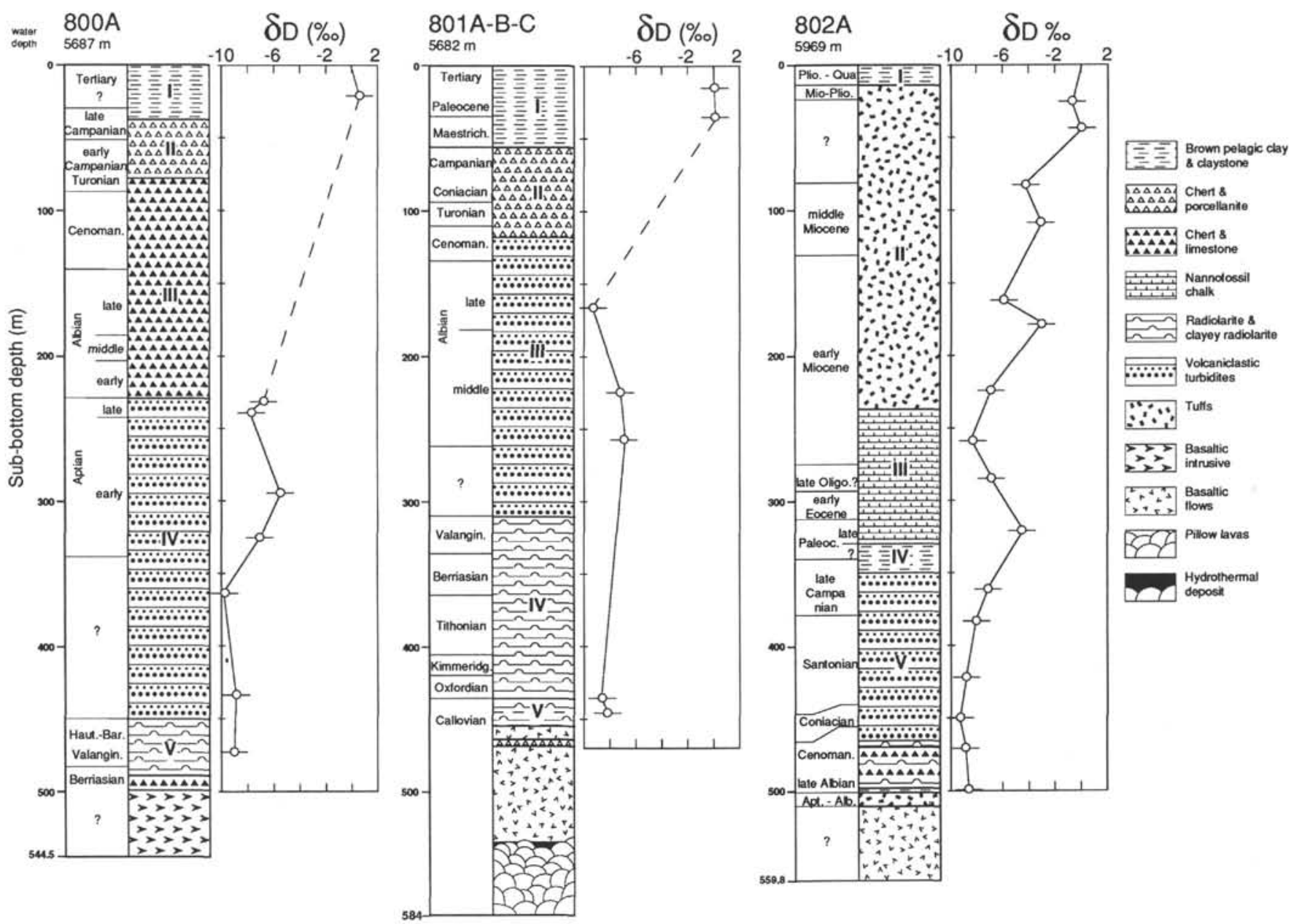

Figure 2. $\delta$ D depth profiles of pore water and lithostratigraphy of Leg 129 Sites 800,801 , and 802.

\section{Site 801-Pigafetta Basin}

This site is situated within the the "Jurassic magnetic quiet zone" in the central part of the Pigafetta Basin to the southeast of Site 800 (Fig. 1) at a water depth of $5674 \mathrm{~m}$. The $462 \mathrm{~m}$ of cored sediment ranges in age from Cenozoic to Callovian and has been divided into five lithologic units ("Site 801" chapter, Lancelot, Larson, et al., 1990) (Fig. 2):

Unit I (0-64 mbsf): Tertiary to Campanian pelagic brown clay.

Unit II (64-126 mbsf): Campanian to Turonian brown chert and porcellanite.

Unit III (126-318 mbsf): Cenomanian and Albian volcaniclastic turbidites. Volcanic material is altered to smectite and celadonite.

Unit IV ( $318-443$ mbsf): Valanginian to Oxfordian brown radiolarite with dark brown chert.

Unit V (443-462 mbsf): Callovian-Bathonian umber radiolarite and claystone.

Basement consists of an upper alkali olivine basalt sequence (462-591 mbsf) and a lower tholeiitic pillow basalt sequence (462$591 \mathrm{mbsf}$ ). These are separated by a silicified hydrothermal deposit of hematite (Alt et al., this volume). This is the first site to recover Jurassic basement in the Pacific.

Seven interstitial water samples were squeezed; two above the chert Unit II and four below (Table 1, Fig. 2). As at Site 800, the depth profile of $\delta \mathrm{D}$ values of pore water is also characterized by a break between modern seawater values above chert Unit II and the D-depleted waters below. In volcaniclastic Unit III, $\delta \mathrm{D}$ values range from $-9.3 \%$ at $175 \mathrm{mbsf}$ to $-6.8 \%$ at $265 \mathrm{mbsf}$. In the lower unit of the hole, $\delta \mathrm{D}$ of pore water from the Jurassic sediments is about $-8.5 \%$.

\section{Site 802-East Mariana Basin}

Located in the center of the East Mariana Basin, Site 802 is more than $300 \mathrm{~km}$ away from any known seamount arc or island (Fig. 1). The water depth is $5674 \mathrm{~m}$. The sediment sequence is $500 \mathrm{~m}$ thick and consists mainly of redeposited volcanic and carbonaceous material of Miocene and Cretaceous age. It has been divided into nine lithologic units ("Site 802" chapter, Lancelot, Larson, et al., 1990) (Fig. 2):

Unit I (0-15 mbsf): Neogene brown clay.

Unit II (15-254 mbsf): Miocene to Eocene tuffs with indurated and well-preserved hyaloclastites and volcaniclastic turbidites. The upper half of the unit is particularly well cemented. There are few layers of pelagic clay, and in the lower half the volcaniclastic material is mixed with chalk. This unit is undergoing active diagenesis and the pore waters are strongly enriched in $\mathrm{Ca}$ and $\mathrm{Cl}$ (France-Lanord et al., this volume).

Unit III (254-330 mbsf): upper Paleocene nannofossil chalk probably redeposited as gravity flow.

Unit IV ( 330-348 mbsf): Maestrichtian zeolitic pelagic claystone.

Unit V (348-460 mbsf): Campanian volcaniclastic turbidites with claystone, porcellanite, and debris flow.

Unit VI to IX (460-509 mbsf): Cenomanian to upper Albian brown claystone, radiolarian limestone, and volcaniclastic turbidites.

Basement consists of remarkably fresh extrusive basalt.

Interstitial-water samples were squeezed from sediment cores at 16 levels in Hole 802A (Table 1, Fig. 2). The samples are evenly distributed between 26 and 500 mbsf. $\delta \mathrm{D}$ values of pore waters decrease rapidly in the upper $80 \mathrm{~m}$ from seawater values at 26 and 44 
Table 1. H-isotope composition of pore water.

\begin{tabular}{|c|c|c|}
\hline $\begin{array}{l}\text { Core, section, } \\
\text { interval }(\mathrm{cm})\end{array}$ & $\begin{array}{l}\text { Deptha } \\
\text { (mbsf) }\end{array}$ & $\begin{array}{l}\delta \mathrm{D} \\
(\% 0)\end{array}$ \\
\hline \multicolumn{3}{|l|}{$129-800 \mathrm{~A}-$} \\
\hline $4 \mathrm{R}-2,25-30$ & 22 & 0.7 \\
\hline $26 \mathrm{R}-2,140-148$ & 232 & -6.7 \\
\hline $27 \mathrm{R}-1,140-150$ & 239 & -7.8 \\
\hline $33 R-6,60-70$ & 296 & -5.5 \\
\hline $37 \mathrm{R}-2,0-10$ & 327 & -7.1 \\
\hline $41 R-2,0-10$ & 364 & -9.8 \\
\hline $49 R-2,140-150$ & 434 & -8.9 \\
\hline $54 \mathrm{R}-2,0-12$ & 473 & -9.0 \\
\hline \multicolumn{3}{|l|}{$129-801 \mathrm{~A}-$} \\
\hline Surface seawater & - & 0.3 \\
\hline $3 R-2,145-150$ & 23 & 0.0 \\
\hline $5 R-2,145-150$ & 44 & 0.3 \\
\hline $19 \mathrm{R}-2,65-73$ & 175 & -9.3 \\
\hline \multicolumn{3}{|l|}{$129-801 \mathrm{~B}-$} \\
\hline $5 R-2,0-10$ & 233 & -7.1 \\
\hline $8 R-3,115-125$ & 265 & -6.8 \\
\hline $33 \mathrm{R}-1,143-150$ & 444 & -8.7 \\
\hline $35 \mathrm{R}-2,0-10$ & 454 & -8.1 \\
\hline \multicolumn{3}{|l|}{$129-802 \mathrm{~A}-$} \\
\hline $4 \mathrm{R}-1,140-150$ & 26 & -0.2 \\
\hline $6 \mathrm{R}-2,0-10$ & 44 & 0.5 \\
\hline $10 \mathrm{R}-2,140-150$ & 83 & -4.0 \\
\hline $13 \mathrm{R}-1,53-58$ & 109 & -2.7 \\
\hline $19 R-2,107-117$ & 162 & -5.8 \\
\hline $21 \mathrm{R}-1,103-110$ & 179 & -2.8 \\
\hline $26 \mathrm{R}-1,0-10$ & 225 & $-6,8$ \\
\hline $29 \mathrm{R}-3,29-34$ & 258 & -8.3 \\
\hline $32 \mathrm{R}-2,140-150$ & 286 & -6.6 \\
\hline $36 \mathrm{R}-1,80-88$ & 322 & -4.2 \\
\hline $40 \mathrm{R}-2,140-150$ & 361 & -7.0 \\
\hline $43 R-1,140-150$ & 384 & -8.0 \\
\hline $47 \mathrm{R}-2,140-150$ & 422 & -8.7 \\
\hline $50 R-2,140-150$ & 450 & -9.2 \\
\hline $53 \mathrm{R}-1,120-130$ & 471 & -8.7 \\
\hline $56 \mathrm{R}-2,140-150$ & 500 & -8.5 \\
\hline
\end{tabular}

Depth rounded to the nearest meter.

mbsf to $-4 \%$ at 83 mbsf. In the tuffs of Unit II, $\delta \mathrm{D}$ values decrease erratically to $-6.8 \%$ at $225 \mathrm{mbsf}$. In the redeposited chalk of Unit III, $\delta \mathrm{D}$ values increase to $-4.2 \%$ at $322 \mathrm{mbsf}$. In the underlying units, $\delta \mathrm{D}$ values are lower, between $-7 \%$ and $-9.2 \%$.

\section{DISCUSSION}

\section{Factors Influencing $\delta \mathrm{D}$ of Pore Waters}

As in most deep-sea holes, $\delta \mathrm{D}$ values of pore water of Leg 129 sites decrease with depth. These isotopic composition depth profiles are the result of the superimposed effects of several factors:

1. The $\delta \mathrm{D}$ of seawater is not constant with time because of variations of the volume of the D-depleted polar caps. Based on the estimated $\delta^{18} \mathrm{O}$ of about - $1 \%$ for pre-14-m.y. ocean water (Shackleton and Kennett, 1975), Sheppard (1977) estimated that $\delta D$ of the same water was about $-7 \%$. Here the major problem is that diffusive sediment-seawater exchange with ocean water at $0 \%$ since about 14 m.y. tends to erase the original composition. The debate turns around the diffusion constant, generally taken to be between $10^{-5}$ to $10^{-6}$ $\mathrm{cm}^{2} / \mathrm{s}$. With such values, Lawrence (1988) has shown that the paleowater signal is almost lost at 400 mbsf after 10 m.y. Bath and Shackleton (1981) and Friedman and Hardcastle (1988), based on the agreement of diffusion models with observed profiles, proposed that the $\delta \mathrm{D}$ of pore water reflects the paleo-water composition modified by diffusion with a diffusion constant of $5 \times 10^{-7}$ to $10^{-7} \mathrm{~cm}^{2} / \mathrm{s}$.
Table 2. Water content and D/H analysis of pore water and total water from three smectite-bearing samples from Hole $800 \mathrm{~A}$, and estimations of the H-isotopic composition of interlayer water.

\begin{tabular}{|c|c|c|c|}
\hline Core, section, interval $(\mathrm{cm})$ : & $37 R-2,0-10$ & $49 \mathrm{R}-2,140-150$ & $54 \mathrm{R}-2.0-12$ \\
\hline \multicolumn{4}{|l|}{ Measurements } \\
\hline$\delta \mathrm{D}$ of pore water $(\% c)$ & -7.1 & -8.9 & -9.0 \\
\hline${ }^{a}$ Water content of adjacent levels & 33 & 29 & $20-24$ \\
\hline$\delta \mathrm{D}$ of total water $(\% c)$ & -11 & -16.1 & -15.7 \\
\hline Total water content $(w t \%)(T)$ & 49.5 & 31.9 & 21.7 \\
\hline$\delta \mathrm{D}$ of hydroxyl $(\%)$ & -48.9 & -53.6 & \\
\hline Hydroxyl (wt $\% \mathrm{H}_{2} \mathrm{O}$, bulk sediment) & 2.1 & 2.2 & 1.6 \\
\hline${ }^{b}$ Smectite content $(S m)$ & 90 & 90 & 35 \\
\hline \multicolumn{4}{|c|}{ Estimations based on interlayer pore-water content $i=15 \mathrm{dry} w \%$} \\
\hline Pore-water content (wt $\%)(P)$ & 43 & 23 & 18 \\
\hline$\delta \mathrm{D}$ of interlayer water $(\%)$ & -36 & -34 & -44 \\
\hline $1000 \ln \alpha_{\text {pore-intertayer }}$ & 29 & 25 & 35 \\
\hline \multicolumn{4}{|c|}{ Estimations based on interlayer pore-water content $i=20 \mathrm{dry} w t \%$} \\
\hline Pore-water content $(w t \%)(P)$ & 40 & 20 & 16 \\
\hline$\delta \mathrm{D}$ of interlayer water $(\%)$ & -28 & -27 & -36 \\
\hline $1000 \ln \alpha_{\text {pore-intertayet }}$ & 21 & 18 & 27 \\
\hline
\end{tabular}

"Based on water content of adjacent levels and similar lithologies ("Physical Properties" section, "Site 800" chapter, Lancelot. Larson, et al., 1990).

${ }^{\mathrm{b}} \mathrm{Percentage}$ of dry weight, estimated from X-ray diffraction determinations and major element analyses (France-Lanord et al., this volume).

2. Diffusional exchange between altered upper basaltic crust and/or seawater through the overlying sediments controls both the major element content (McDuff, 1981) and $\delta^{18} \mathrm{O}$ (Lawrence and Gieskes, 1981) of pore water in unreacting sediments. With time, its effect on $\delta \mathrm{D}$ should tend to smooth the isotopic depth profiles and to reduce the differences between paleo-seawater and actual seawater. In reacting sediments or basalts the situation is probably very different because hydroxylated minerals are generaly depleted in D relative to pore water, the alteration of the basaltic basement should tend to enrich the pore water in D. This is in the opposite sense of that observed in the profiles. The upper basaltic crust may also constitute a reservoir of pre-Miocene D-depleted seawater.

3. Ultrafiltration in compacted clays acting as a semipermeable membrane has been experimentally demonstrated to retain $\mathrm{D}$ (Coplen and Hanshaw, 1973). This process requires cross-formational flow and generates both enriched and depleted waters. It is more likely to generate D enrichment in the residual reservoir rather than significant $\mathrm{D}$ depletion in the filtrated waters, because of the reservoir effect.

4. Direct or indirect transformation of organic matter can produce extremely low D $(\delta \mathrm{D}<-90 \%)$ waters (Sheppard and Charef, 1986; Sheppard, 1986). In our samples the organic C content is typically less than 0.1 wt\% (Lancelot, Larson, et al., 1990) and cannot be a significant source of hydrogen.

5. Mantle degassing has been proposed by Lawrence and Taviani (1988) based on the coexistence of low- $\delta^{13} \mathrm{C}$ carbonates $(-30 \%)$ with low- $\delta \mathrm{D}$ pore water $(\delta \mathrm{D}>-14 \%)$. They argued that low $\mathrm{D}$ water could be produced by oxidation, in the basaltic crust, of $\mathrm{H}_{2}$ and $\mathrm{CH}_{4}$ from the mantle.

6. Alteration of basaltic material into clays and zeolites can occur either in the sediment or in the underlying upper basaltic crust. This 
has been demonstrated to deplete the pore waters in ${ }^{18} \mathrm{O}$ (Lawrence, 1973; Gieskes and Lawrence, 1981). As is observed for Samples 129-800A-37R-2, 0-10 cm, and 129-800A-49R-2, 140-150 cm (Table 2), hydroxyl of newly formed clays is depleted in D relative to water by about $40 \%$ to $80 \%$ (Savin and Epstein, 1970). Clay formation should therefore generate D enrichment in the pore water. However, this effect is limited because in a pure smectitic sediment, octahedral hydroxyl represents only about $5 \mathrm{~mol} \%$ of the total hydrogen (hydroxyl plus sorbed and pore water). Lawrence and Gieskes (1981) have proposed that the fractionation between pore water and smectite is essentialy zero if interlayer water is included with hydroxyl in the smectite. Therefore, it is essential to take into account the interlayer water of smectites and the channel water in zeolites.

\section{$\delta$ D Values of Interlayer Water}

Based on the analyses of pore water and total water (i.e., sorbed + pore) of bulk sediments (Table 2) the isotopic composition of sorbed water can be estimated by the difference. The mass balance equation for hydrogen in the bulk sediment is

$$
B \delta \mathrm{D}_{\text {bulk }}=P \delta \mathrm{D}_{\text {pore }}+S \delta \mathrm{D}_{\text {sorbed }}+H \delta \mathrm{D}_{\text {hydroxyl, }}
$$

where $B, P$, and $S$ are the hydrogen contents in the bulk sediment, pore water, and sorbed water, respectively, and $H$ is the hydroxyl in the bulk sediment. $B, P, S$, and $H$ may be expressed in weight percentage of either $\mathrm{H}_{2}$ or $\mathrm{H}_{2} \mathrm{O}$ relative to the bulk sample. Assuming that the hydroxyl hydrogen is nonexchangeable and not extracted at temperatures lower than $140^{\circ} \mathrm{C}$ (e.g., Sheppard et al., 1969; Savin and Epstein, 1970), this equation can be simplified to a mass balance equation for total water,

$$
T \delta \mathrm{D}_{\text {total }}=P \delta \mathrm{D}_{\text {pore }}+S \delta \mathrm{D}_{\text {sorbed, }}
$$

where $T$ is the total water content in the bulk sediment. For our samples, sorbed waters are dominated by interlayer water because zeolites are essentially absent and absorbed water is probably very minor. Thus,

$$
\delta \mathrm{D}_{\text {interlayer }}=\frac{T \times \delta \mathrm{D}_{\text {total }}-P \times \delta \mathrm{D}_{\text {pore }}}{I},
$$

where $I$ is the interlayer water content of the bulk sediment. As

$$
T=P+I,
$$

the pore-water content and the interlayer water content are interdependent. $T$ is measured during the extraction of total water (Table 2) but $P$ and $I$ are not known. To estimate the $\delta \mathrm{D}$ value of interlayer water it is therefore necessary to determine either $P$ or $I$. Shipboard measurements of physical properties include data that are related to porewater contents. These data, which are for levels adjacent to our samples (Table 2), were not used for $P$ because (1) measurements were not made on our exact samples, and (2) they represent values intermediate between $P$ and $P+I$ because grain density is measured after drying at $105^{\circ} \mathrm{C}$ for one day and therefore after partial dehydration of interlayer water (see also Egeberg et al., 1990). I, the weight ratio of interlayer water to bulk sediment, is a function of $T$, of the interlayer water content of the smectite $i$ (the weight ratio of interlayer water/dry smectite in wt\%), and of $\mathrm{Sm}$, the smectite content of the dry sediment (in wt\%):

$$
I=\frac{i}{100} \times\left[\frac{S m}{100}(100-T)\right]
$$

Combining equations 3,4 , and $5, \delta \mathrm{D}_{\text {interlayer }}$ can be calculated from the measurements of $\delta \mathrm{D}_{\text {total }}, \delta \mathrm{D}_{\text {pore }}$, and $T$ (Table 2) and estimates of $\delta \mathrm{D}_{\text {total }}$, $\delta \mathrm{D}_{\text {pore }}$, and $T$ (Table 2) and from estimates of $i$ and $S m$. Figure 3 presents

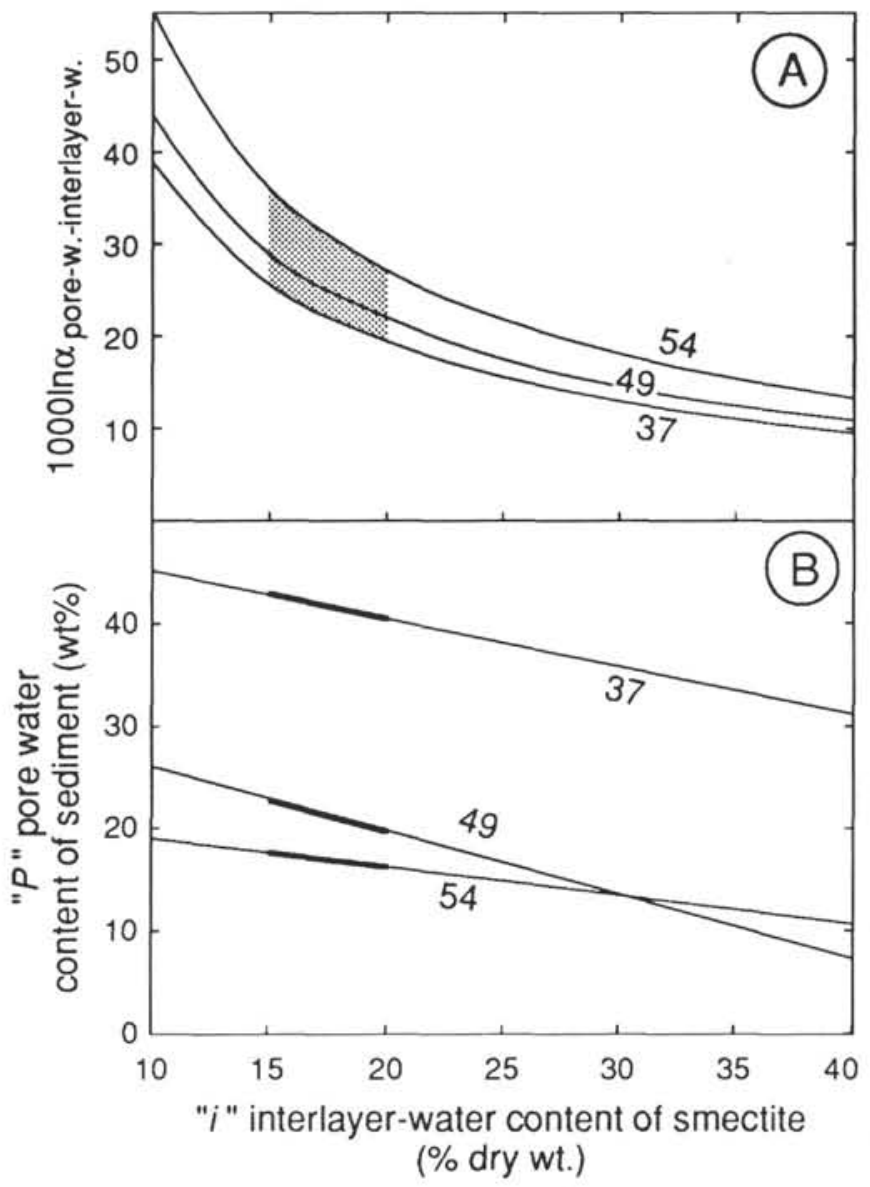

Figure 3. Variation of (A) hydrogen isotopic fractionation between pore and interlayer waters and $(\mathbf{B})$ pore-water content of the sediment $(P)$, as a function of the interlayer water content of smectite $(i)$. Labels 37,49 , and 54 refer to Samples $129-800 \mathrm{~A}-37 \mathrm{R}-2,0-10 \mathrm{~cm}, 129-800 \mathrm{~A}-49 \mathrm{R}-2,140-150 \mathrm{~cm}$, and $129-800 \mathrm{~A}-54 \mathrm{R}-2,0-12 \mathrm{~cm}$, respectively. The calculations take into account the $\delta \mathrm{D}$ values of pore and total waters and the amounts of total water $(T)$ and of smectite $(\mathrm{Sm})$ in each sample. The shaded area (A) and the thicker lines (B) correspond to interlayer water content of smectite between 15 and $20 \%$ dry weight, which are plausible values in the P-T conditions of Units IV and V.

the pore-water content and the $\mathrm{H}$ isotopic fractionation between pore and interlayer water $\left(1000 \ln \alpha_{\text {pore-interlayer }}\right)$ as a function of the interlayer water content of the smectite $i$. The agreement among the three independent pore-interlayer fractionation curves is quite good if we consider all the uncertainties on the different variables. Uncertainty of the smectite content is important and can be estimated. Changing $\mathrm{Sm}$ from $90 \mathrm{wt} \%$ to $70 \mathrm{wt} \%$ will reduce $\delta \mathrm{D}_{\text {interlayer }}$ by $\approx 7 \%$ and hence increase the fractionation factor. The interlayer water content of the smectite $i$ is mainly dependent on the temperature and the pressure (Bird, 1984), whereas the chemical composition of the smectite is a less important factor (e.g., Newman, 1987). Following Bird (1984), the interlayer water content of smectite can be estimated to be between $15 \%$ and $20 \%$ of the dry weight (dry wt\%) under the $P-T$ conditions of Units IV and V at Site 800 . For these two values, the estimated pore-water contents and pore-interlayer fractionations are given in Table 2. The pore-interlayer water fractionation is thus estimated to be about 20 to 30 . These fractionations are in the same sense and of the same order of magnitude as those determined from preliminary experiments using pure montmorillonite (Taïeb, 1986). A single value of the fractionation factor is not to be expected as the factor is probably a function of temperature, fluid pressure, interlayer cation, number of interlayers, and other parameters. Lawrence and Taviani (1988) however have suggested that interlayer water is enriched by about 


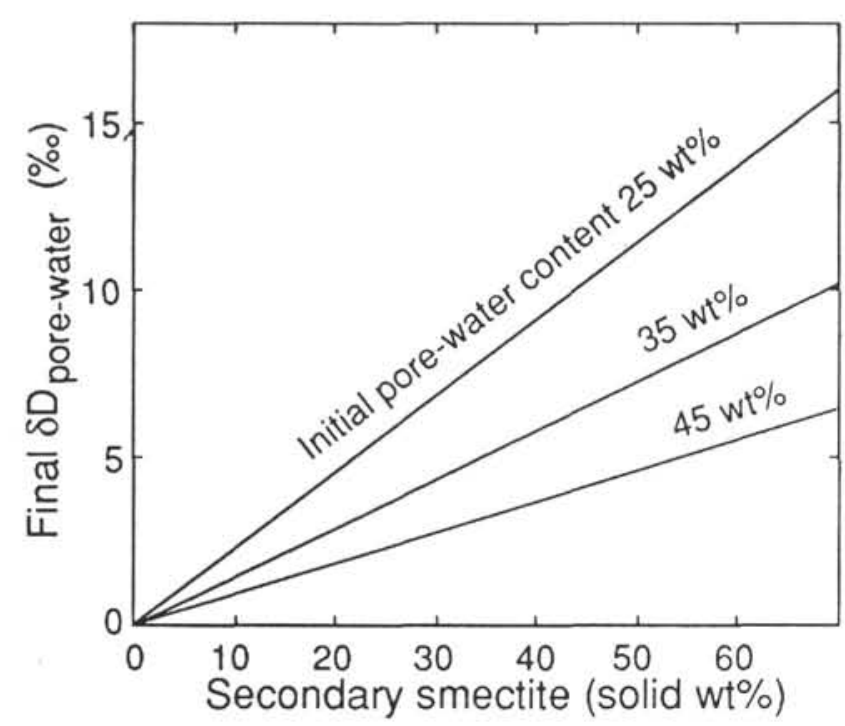

Figure 4. Model evolution of pore-water $\delta \mathrm{D}$ through alteration of volcanic ash into smectite for different initial water contents of the sediment. Conditions of the model are: closed system, initial pore-water $\delta \mathrm{D}=0 \%$, $1000 \ln \alpha_{\text {pore-interlayer }}$ $=20,1000 \ln \alpha_{\text {pore-hydroxyl }}=40$, interlayer water content $0.20 \%$ dry wt. The change resulting from the hydroxyl uptake is approximated to a batch change instead of a Rayleigh distillation because the fraction of the initial pore-water hydrogen that is frozen as hydroxyl never exceed 0.2

$20 \%$ relative to pore water, based on a comparison that interlayer water has an ice-like structure. This is in the opposite sense of our results.

Figure 4 illustrates the change in $\delta \mathrm{D}$ of pore water during closedsystem alteration of volcanic ash to smectite for different initial pore-water contents. This model includes the uptake of hydrogen in both the hydroxyl and the interlayer sites of the smectite. The importance of the increase is, of course, highly dependent on the porosity. The $\delta \mathrm{D}$ increases shown on Figure 4 are, however, extreme estimates because natural systems are rarely closed. Additionally, the formation of zeolites will increase the shift because channel water is even more D depleted (Karlsson and Clayton, 1990) than interlayer water. D enrichment of pore waters due to mineral formation should be more favorable in those particular formations where diffusion effects are at a minimum, such as it is in Unit II of Site 802.

\section{Sites 800 and 801}

At Sites 800 and 801 the concentrations below the chert and radiolarite units are almost constant. These values probably reflect the absence or the very low rate of diffusion due to the overlying chert. The diffusion coefficient in sediments qualitatively decreases with lower sediment porosities and higher resistivities (Manheim and Waterman, 1974; McDuff and Gieskes, 1976). At Site 800, the porosity is $10 \%-30 \%$ in the chert instead of $30 \%-60 \%$ in the volcaniclastics (Lancelot, Larson, et al., 1990). Phasor induction resistivities in Hole $800 \mathrm{~A}$ show that chert layers are characterized by $6-9$ ohm-m resistivities that are significantly higher than in other formations $(0.5$ to 3 ohm-m in lithologic Units III and IV) (Lancelot, Larson, et al., 1990). At Site 801, sediment resistivities are also high, from 2 to $6 \mathrm{ohm}-\mathrm{m}$, and porosities are very low, between $8 \%$ and $20 \%$ (Lancelot, Larson, et al., 1990). Therefore, the break in the profiles is consistent with a low diffusion coefficient in the chert units at both sites. Similar breaks are observed for major cation concentration profiles (France-Lanord et al., this volume). This type of lithologic barrier to diffusion is highly efficient. For instance, at DSDP Site 462, an 80-m-thick chert layer is present at $400 \mathrm{mbsf}$ and concentrations above the chert are similar to seawater and they are also nearly constant below the cherts but with
Ca close to $50 \mathrm{mmol}$ and $\mathrm{Mg}$ depleted to $<10 \mathrm{mmol}$ (Gieskes and Johnson, 1981). At both Sites 800 and 801 , the chert units are Cretaceous. Hence, the seawater trapped in the sediments should have had an original $\delta D$ value lower (about $-7 \%$ ) than that of modern seawater. The present pore-water $\delta \mathrm{D}$ values may reflect original compositions unmodified by diffusional exchange if the chert barrier was established before the Miocene. If the system was closed to overlying seawater, it probably remained open to basement. The latter may be either a reservoir of paleo-seawater or a reservoir of pore water enriched in $\mathrm{D}$ by alteration reactions. Due to the mass balance between hydrogen in pore water and in D-depleted hydroxyl in the mineral structures, it is unlikely that alteration will produce large $\mathrm{D}$ variations. No differences are observed between $\delta \mathrm{D}$ pore water from the bottoms of Holes 800A and 801B despite the differences in $\mathrm{Mg}$ and $\mathrm{Ca}$ contents. Site 801 pore waters are poorly depleted in $\mathrm{Mg}$ and enriched in $\mathrm{Ca}$ at depth compared with those at Site 800 , indicating a lower degree of alteration of basement or a low degree of exchange with the basement. This is consistent with a minor role of basement alteration on $\mathrm{D} / \mathrm{H}$ variations. In-situ alteration of volcanic ash that may be inferred from the major cation chemistry in Unit IV at Site 800 and in Unit III at Site 801 is far too low to be detected by $\delta \mathrm{D}$ of pore water.

\section{Site 802}

At Site 802 the $\delta D$ depth profile shows a relatively regular D depletion with depth. Such a profile corresponds to the type commonly observed at most DSDP-ODP sites (e.g., Friedman and Hardcastle, 1988). However, the lithology is not usual and the upper tuff Unit II is undergoing active diagenesis characterized by significant increase of $\mathrm{Cl}$ and $\mathrm{Ca}$ in the pore waters. High $\mathrm{Cl}$ concentration (630 $\mathrm{mmol}$ ) results from the uptake of water by the formation of secondary hydrous minerals. A closed-system model of alteration shows that, depending on the porosity, about 25 to $50 \mathrm{wt} \%$ of the initial volcanic material must be altered into smectites and zeolites to explain this $\mathrm{Cl}$ rise (France-Lanord et al., this volume). Comparable pore-water concentrations have been reported only at ODP Sites 792 and 793 (Egeberg et al., 1990), where a similar lithology is observed. More recently, comparable pore waters were sampled in volcaniclastic sediments during Legs 134 and 135 (Collot, Greene, Stokking, et al., 1992; Parson, Hawkins, Allan, et al., 1992). Pore-water profiles of major elements show very high gradients in the upper $80 \mathrm{~m}$. The preservation of such extreme concentrations at $80 \mathrm{mbsf}$ implies very low rates of diffusion combined with high sedimentation rates. Unfortunately, no downhole measurements are available for the upper $100 \mathrm{~m}$, but between 100 and $140 \mathrm{mbsf}$, measured sonic velocities and resistivities are highly variable ( 2 to $4 \mathrm{~km} / \mathrm{s}$ and 2 to $200 \mathrm{ohm}-\mathrm{m}$, respectively; "Site 802" chapter, Lancelot, Larson, et al., 1990). These high sonic velocity and resistivity levels correspond to intervals of coarse sandy tuff strongly cemented by silica (Karpoff et al., this volume) and their high degree of cementation is likely to be responsible for low diffusion. Similar intervals are probably present in the upper parts of the unit because the lithology is the same. The existence of zones with low diffusion coefficient levels is also supported by measurement of formation factors in a similar lithology at Sites 792 and 793 (Taylor, Fujioka, et al., 1990).

The pore waters of Site 802 show a broad correlation between $\delta \mathrm{D}$ and $\mathrm{Cl}$ content (Fig. 5) except for the two upper samples which are close to the seawater interface and have values similar to that of modern seawater. Two factors may significantly influence the $\delta \mathrm{D}$ values of pore-waters in the top section of Site 802 . First, the presence of diffusion barriers should have reduced the extent of exchange with modern seawater and therefore preserved Miocene seawaters with lower $\delta \mathrm{D}$. Second, alteration reactions with the volcanic ash may induce a $\mathrm{D}$ enrichment of the pore water. In a simple closed-system model of volcanic ash being altered into smectite, a plot of $\mathrm{Cl}$ content against $\delta \mathrm{D}$ of pore waters shows a $\delta \mathrm{D}$ increase of $4.5 \%$ for a $85 \mathrm{mmol} \mathrm{Cl}$ increase (Fig. 5). For the Site 802 


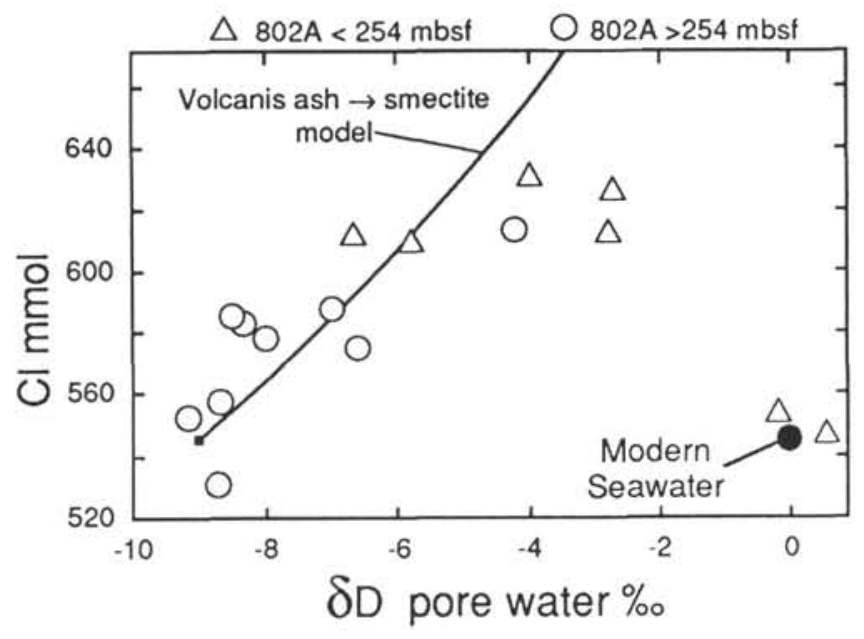

Figure 5. Pore-water $\delta \mathrm{D}$ vs. $\mathrm{Cl}$ content shows a broad correlation for Site 802 samples. Model variation due to diagenesis of volcanic ash to smectite is given for the same conditions as in Figure 4, except that initial pore-water $\delta \mathrm{D}=-9 \%$. Initial $\mathrm{Cl}$ content $=545 \mathrm{mmol}$.

tuffs, if the system is closed, the model probably underestimates the $\delta \mathrm{D}$ increase because zeolites are abundant (Karpoff et al., this volume) and they take up D depleted $\mathrm{H}_{2} \mathrm{O}$ (Karlsson and Clayton, 1990). The high $\delta \mathrm{D}$ and $\mathrm{Cl}$ contents of the Miocene tuff samples could correspond to an enrichment coming from alteration reactions with pore waters of the underlying levels, representing the initial paleo-seawater composition ( $-9 \% \circ \delta \mathrm{D}, 545 \mathrm{mmol} \mathrm{Cl}$ ).

The effect of diffusion with seawater is difficult to estimate because the diffusion coefficients are unknown. However, the fact that the percentage of alteration observed in the tuffs ("Site 802" chapter, Lancelot, Larson, et al., 1990) is similar to that calculated from the $\mathrm{Cl}$ rise due to alteration of volcanic ash in a closed-system model implies very low diffusion rates in the tuffs (France-Lanord et al., this volume). Figure 6 presents a $\delta \mathrm{D}$ depth profile for pore waters calculated for a simple diffusion model (e.g., Turcotte and Schubert, 1982),

$$
\frac{\delta \mathrm{D}_{\text {pore }}-\delta \mathrm{D}_{\text {initial }}}{\delta \mathrm{D}_{\text {seawater }}-\delta \mathrm{D}_{\text {initial }}}=\operatorname{erfc} \frac{Z}{2 \sqrt{D t}},
$$

where $D$ is the diffusion constant, $\delta \mathrm{D}_{\text {initial }}$ corresponds to pre-Miocene seawater assumed to be $-9 \%$, $z$ is the sub-bottom depth, $t$ is the time span since an instantaneous $\delta \mathrm{D}$ change in the ocean from $-9 \%$ to 0 , taken to be 14 m.y. and erfc is the complementary error function. The two profiles are for (1) $D_{s w}$, the diffusion coefficient of deuterium in $35 \% 0 \mathrm{NaCl}$ solution at $1.3 \times 10^{-5} \mathrm{~cm}^{2} / \mathrm{s}$ (Tanaka, 1975), which is an upper limit, and (2) $D_{\text {sed }}\left(4 \times 10^{-7} \mathrm{~cm}^{2} / \mathrm{s}\right)$ which is consistent with the Site 802 profile. If, as proposed by Manheim and Waterman (1974), the diffusion coefficient is proportional to $1 / P F$, where $P$ is the fractional porosity and $F$ the formation factor, $D_{\text {sed }}$ is not unreasonable. In the tuffs, $F$ is likely to be ten times higher than it is in less cemented sediments (i.e., with lower resistivity) by analogy with similar formation at Site 793 (Taylor, Fujioka, et al., 1990), and $P$ in the tuff reaches values as low as $10 \%$ ("Site 800 " chapter, Lancelot, Larson, et al., 1990). Assuming that $D_{\text {sed }}$ is correct, slight enrichments in deuterium of pore water compared to the pure diffusion model could result from alteration reactions. Although there is a very large uncertainty with the diffusion constant $D_{\text {sed }}$, it is reasonable to propose that isotopic compositions of $\mathrm{H}$ of pore water in Unit II correspond to paleo-seawater modified by diffusion and alteration reactions. The lower part of the $\delta \mathrm{D}$ profile (below $250 \mathrm{mbsf}$ ) is almost vertical at about $-8 \%$ except at 322 mbsf (Fig. 2). Here, as at Site 800 , the vertical gradient suggests the absence of significant diffusion from basement.

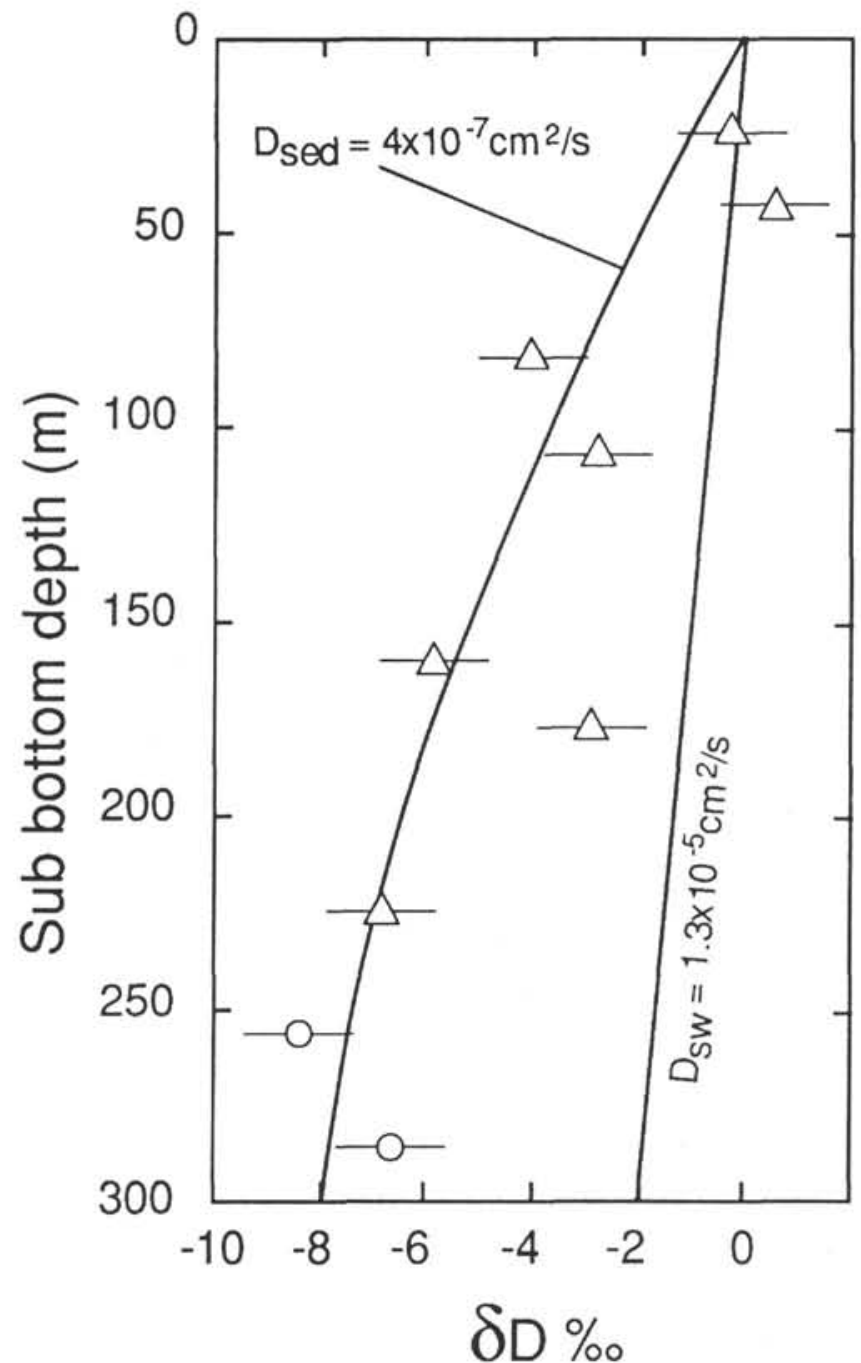

Figure 6. Site 802 pore-water $\delta D$ vs. depth in the upper volcaniclastic tuffs. The curves illustrate the effect of diffusion with ocean water with initial pore-water $\delta \mathrm{D}=-9 \%$ and a rapid change of $\delta \mathrm{D}$ of seawater from $-9 \%$ to $0 \%$ that occurred 14 m.y. ago.

\section{CONCLUSIONS}

1. $\delta \mathrm{D}$ of total water from sediment containing smectite indicates that sorbed (interlayer plus absorbed) waters are depleted in D compared with pore water. At plausible porosity values, the per mil fractionation between pore water and interlayer water is estimated to be $20 \%$ to $30 \%$. In a smectite-rich sediment, interlayer water may represent 15 to $50 \mathrm{~mol} \%$ of the total hydrogen. Therefore, the formation of smectite during diagenesis may induce a D enrichment of the pore water.

2. Alteration of volcanic ash into secondary hydrous minerals may produce a D enrichment of pore water. However, significant shifts will be observed only in essentially closed systems, where alteration is greater than $20 \%$ to $30 \%$. Such conditions are present in the Miocene volcaniclastic tuff at Site 802 . Sites with similarly high $\mathrm{Cl}$ and $\mathrm{Ca}$ pore waters are characterized by very high sedimentation rates, fresh volcanic sediments, and efficient cementation.

3. Diffusional exchange either with the ocean or the upper igneous crust does not necessarily erase the $\delta \mathrm{D}$ value of paleo-seawater. At Sites 800 and 801 , the presence of chert intervals reduces diffusional 
exchange with seawater and, therefore, $-10 \%$ to $-8 \%$ pore waters probably represent little modified paleo-seawater compositions. Diffusion from basement is an alternative posssibility if basement represents a reservoir at $-10 \%$. However, diffusion from basement seems to be minor from the major cation profiles at Site 801 . At Site 802 diffusion is probably limited to the upper tuff unit.

\section{ACKNOWLEDGMENTS}

Support for research was provided by a grant from CNRS ASP Soutien ODP-France and CNRS DBT Fluides et cinétique. Merci to Scott Chaffey, who learned how to seal a quartz tube with a cutting torch, to Pierre Coget for help in the isotopic laboratory, and to Etienne Deloule and James Lawrence for scientific discussions. CRPG contribution no. 888 and CNRS-INSU-DBT thème Fluide minéraux et cinétique no. 397.

\section{REFERENCES}

Bath, A., and Shackleton, N., 1981. Oxygen and hydrogen isotope studies in squeezed pore-waters, Deep Sea Drilling Project Leg 74, Hole 525B: evidence for Mid-Miocene ocean isotopic change. In Moore, T. C., Jr., Rabinowitz, P. D., et al., Init. Repts. DSDP, 74: Washington (U.S. Govt. Printing Office), 697-699.

Bigeleisen, J., Perlman, M. L., and Prosser, H. C., 1952. Conversion of hydrogenic material to hydrogen for isotopic analyses. Anal. Chem., 24:1356-1357.

Bird, P., 1984. Hydration-phase diagrams and friction of montmorillonite under laboratory and geologic conditions, with implications for shale compaction, slope stability, and strength of fault gouge. Tectonophysics, 107:235-260.

Collot, J.-Y., Greene, H. G., Stokking, L. B., et al., 1992. Proc. ODP, Init. Repts., 134: College Station, TX (Ocean Drilling Program).

Coplen, T. B., and Hanshaw, B. B., 1973. Ultrafiltration by a clay membrane. I. Oxygen and hydrogen isotopic fractionation. Geochim. Cosmochim. Acta, 37:2295-2310.

Egeberg, P. K., and the Leg 126 Shipboard Scientific Party, 1990. Unusual composition of pore-water found in the Izu-Bonin fore-arc sedimentary basin. Nature, 344:215-218.

Friedman, I., and Hardcastle, K., 1988. Deuterium in interstitial water from deep-sea cores. J. Geophys. Res., 93:8249-8263.

Gieskes, J. M., and Johnson, J., 1981. Interstitial water studies, Leg 61. In Larson, R. L., and Schlanger, S. O., et al., Init. Repts. DSDP, 61: Washington (U.S. Govt. Printing Office), 603-605.

Gieskes, J. M., and Lawrence, J. R., 1981. Alteration of volcanic matter in deep sea sediments: evidence from the chemical composition of interstitial waters from deep sea drilling cores. Geochim. Cosmochim. Acta, 45:1687-1703.

Karlsson, H. R., and Clayton, R. N., 1990. Oxygen and hydrogen isotope geochemistry of zeolites. Geochim. Cosmochim. Acta, 54:1369-1386.

Lancelot, Y., Larson, R. L., et al., 1990. Proc. ODP, Init. Repts., 129: College Station, TX (Ocean Drilling Program).

Lawrence, J. R., 1973. Interstitial water studies, Leg 15-Stable oxygen and carbon isotope variations in water, carbonates and silicates from the Venezuela Basin (Site 149) and the Aves Rise (Site 148). In Heezen, B. C., MacGregor, I. D., et al., Init. Repts. DSDP, 20: Washington (U.S. Govt. Printing Office), 891-899.

, 1988. The stable isotope geochemistry of deep sea pore-water. In Fritz, B., and Fontes, J. C. (Ed.), Handbook of Environmental Geochemistry, Amsterdam (Elsevier), 3:317-356.

Lawrence, J. R., and Gieskes, J. M., 1981. Constaints on water transport and Alteration in the oceanic crust from the isotopic composition of pore-water. J. Geophys. Res., 86:7924-7934.
Lawrence, J. R., and Taviani, M., 1988. Extreme hydrogen, oxygen and carbon isotope anomalies in the pore-waters and carbonates of the sediments and basalts from the Norwegian Sea: methane and hydrogen from mantle? Geochim. Cosmochim. Acta, 52:2077-2083.

Manheim, F. T., and Sayles, F. L., 1974. Composition and origin of interstitial water of marine sediments based on deep sea drilled cores. In Goldberg, E. D. (Ed.), The Sea (Vol. 5): New York (Wiley Interscience), 527-568.

Manheim, F. T., and Waterman, L. S., 1974. Diffusimetry (diffusion constant estimation) on sediment cores by resistivity probe. In von der Borch, C. C., Sclater, J. G., et al., Init. Repts. DSDP, 22: Washington (U.S. Govt. Printing Office), 663-670.

McDuff, E., 1981. Major cation gradients in DSDP interstitial water: the role of diffusive exchange between seawater and upper oceanic crust. Geochim. Cosmochim. Acta, 34:105-120.

McDuff, E., and Gieskes, J. M., 1976. Calcium and magnesium profiles in DSDP interstitial waters: diffusion or reaction? Earth Planet. Sci. Lett. 33:1-10.

Moum, J., and Rosenqvist, I. Th., 1958. Hydrogen (protium)-deuterium exchange in clays. Geochim. Cosmochim. Acta, 14:250-252.

Newman, A.C.D., 1987. Chemistry of Clays and Clay Minerals. London (Longman Sci. and Tech.).

Parson, L., Hawkins, J., Allan, J., et al., 1992. Proc. ODP, Init. Repts., 135: College Station, TX (Ocean Drilling Program).

Savin, S. M., and Epstein, S., 1970. The oxygen and hydrogen isotope geochemistry of clay minerals. Geochim. Cosmochim. Acta, 34:25-42.

Shackleton, N. J., and Kennett, J. P., 1975. Paleotemperature history of the Cenozoic and the initiation of Antarctic glaciation: oxygen and carbon isotope analyses in DSDP Sites 277, 279 and 281. In Kennett, J. P., Houtz, R. E., et al., Init. Repts. DSDP, 29: Washington (U.S. Govt. Printing Office), 743-756.

Sheppard, S.M.F., 1977. The identification of the origin of ore-forming solutions by the use of stable isotopes. In Volcanic Processes in Ore Genesis. Inst. Mining Metall. Geol. Soc., 25-41.

1986. Characterization and isotopic variations in natural waters. In Valley, J. W., Taylor, H. P., and O'Neil, J. R. (Eds.), Stable Isotope in High Temperature Geological Processes. Rev. in Mineral., Mineral. Soc. Am., 16:165-183.

Sheppard, S.M.F., and Charef, A., 1986. Eau organique: caractérisation isotopique et évidence de son rôle dans le gisement $\mathrm{Pb}$ - $\mathrm{Zn}$ de Fedj-el-Adoum, Tunisie. C. R. Acad. Sci. Ser. 2, 302:1189-1192.

Sheppard, S.M.F., Nielsen, R. L., and Taylor, H. P., 1969. Oxygen and hydrogen isotope ratios of clay minerals from porphyry copper deposits. Econ. Geol., 64:755-777.

Taïeb, R., 1986. Contribution à l'étude du fractionnement de l'hydrogène à température ambiante entre l'eau échangeable (interfoliiaire et absorbée) de la montmorillonite et de l'eau libre liquide. Mem. de DEA, Inst. Nat. Polytech. de Lorraine.

Tanaka, K., 1975. Measurements of self diffusion coefficient of water in pure water and in aqueous electrolyte solutions. J. Chem. Soc. Faraday Trans. 1. 71:1127-1131.

Taylor, B., Fujioka, K., et al., 1990. Proc. ODP, Init. Repts., 126: College Station, TX (Ocean Drilling Program).

Turcotte, D. L., and Schubert, G., 1982. Geodynamics: Applications of Continuum Physics to Geological Problems: New York (Wiley).

Yeh, H., 1980. D/H ratio and late stage dehydration of shale during burial. Geochim. Cosmochim. Acta, 44:341-352.

Date of initial receipt: 3 June 1991

Date of acceptance: 6 January 1992

Ms 129B-126 